\title{
Influence of surrounding land-use on mussel growth and glycogen levels in the St. Croix and Minnesota River Basins
}

\author{
Daniel J. Hornbach (D) Hayley N. Stutzman • Mark C. Hove • Jessica L. Kozarek • \\ Kelly R. MacGregor • Teresa J. Newton • Patricia R. Ries
}

Received: 30 September 2018/Revised: 22 June 2019/ Accepted: 2 July 2019/Published online: 31 July 2019

(C) The Author(s) 2019, corrected publication August 2019

\begin{abstract}
Freshwater mussels face threats from climate change and changing land use that are dramatically altering their habitat. The health of mussel populations and the state of current and past environmental conditions can be monitored by measuring mussel growth and glycogen levels. In this study, we measured growth and glycogen levels in mussels from two small river basins impacted by different land uses. The Snake River in the St. Croix Basin, Minnesota, had low levels of suspended sediments and was surrounded mostly by forest and some developed land. The Chippewa,
\end{abstract}

The original version of this article was revised due to a retrospective Open Access order

Guest editors: Manuel P. M. Lopes-Lima, Nicoletta Riccardi, Maria Urbanska \& Ronaldo G. Sousa / Biology and Conservation of Freshwater Molluscs

D. J. Hornbach $(\bowtie)$

Department of Environmental Studies, Macalester College, 1600 Grand Ave., St. Paul, MN 55105, USA

e-mail: hornbach@macalester.edu

\section{H. N. Stutzman}

Department of Biology, Macalester College, 1600 Grand Ave., St. Paul, MN 55105, USA

\section{C. Hove}

Department of Fisheries, Wildlife and Conservation Biology, University of Minnesota, 131 Hodson Hall, 1980

Folwell Avenue, St. Paul, MN 55108, USA
Cottonwood, and Le Sueur rivers in the Minnesota River Basin had significantly higher annual suspended sediment loads and highly agricultural basins. Mussel growth was highest in the Le Sueur and Cottonwood rivers followed by the Chippewa and the Snake rivers. Mussels in the Minnesota Basin rivers all had higher mussel foot glycogen concentrations than the Snake River. These patterns were similar for two mussel species, suggesting that environmental conditions are likely determining levels of growth. Although agriculture had a negative effect on mussel population abundance and diversity, it had a positive effect on growth and glycogen levels.

\author{
J. L. Kozarek \\ St. Anthony Falls Laboratory, University of Minnesota, 2 \\ SE 3rd Ave., Minneapolis, MN 55455, USA \\ K. R. MacGregor \\ Department of Geology, Macalester College, 1600 Grand \\ Ave., St. Paul, MN 55105, USA \\ T. J. Newton · P. R. Ries \\ Upper Midwest Environmental Sciences Center, U.S. \\ Geological Survey, 2630 Fanta Reed Rd., La Crosse, \\ WI 54603, USA
}


Keywords Freshwater mussels - Agriculture . Glycogen · Growth

\section{Introduction}

Agricultural land use can result in increased nutrient and sediment loads in aquatic systems (Helton et al., 2011; Hladyz et al., 2011; Schilling et al., 2012; Woodward et al., 2012; Garcia et al., 2017). Freshwater mussels are among the most endangered organisms in freshwater (Strayer et al., 2004; Haag, 2012; Lopes-Lima et al., 2018); they are important in stream systems as "ecosystem engineers." They can influence nutrient cycling and primary production through their filter feeding and excretion (Newton et al., 2011; Atkinson et al., 2013; Strayer, 2014), and through burrowing can modify the benthic environment (Gutiérrez et al., 2003; Allen \& Vaughn, 2011; Albertson \& Allen, 2015; Chowdhury et al., 2016). A number of studies have suggested that increased levels of agricultural activity in a basin may have significant impacts, reducing freshwater mussel abundance and richness (Arbuckle \& Downing, 2002; Poole \& Downing, 2004; Atkinson et al., 2014; Cao et al., 2013, 2015; Randklev et al., 2016). Despite these studies, the disentangling of factors (e.g. increased sedimentation, nutrient loading, pesticides and herbicides) responsible for negative impacts on mussel communities is difficult (Brim Box \& Mossa, 1999; Newton et al., 2008; Haag, 2012).

Many studies of the impact of agriculture on mussel abundance focus on the likely influence that high amounts of total suspended solids (TSS - both organic and inorganic materials) in agricultural streams have on these filter feeding organisms. Hansen et al. (2016), modeling the relationship between mussel density and TSS concentrations, found that under scenarios of increased sediment loads, mussel density may decline. They also found that there was an important feedback between mussel populations and suspended sediment loads, with larger populations of mussels moderating the amount of suspended solids in the water column. High concentrations of suspended solids, especially the inorganic fraction of TSS, promote lower mussel abundance through reduced recruitment (Österling et al., 2010; Gascho Landis et al., 2013; Österling, 2015; Gascho Landis \& Stoeckel, 2016), inducing physiological stress (Aldridge et al., 1987; Payne et al., 1999) and reducing feeding/clearance rates (Moore, 1977; Hornbach et al., 1984; Vaughn \& Hakenkamp, 2001; Gascho Landis et al., 2013). Biological mechanisms through which TSS affected gravidity were hypothesized to be either that highinorganic TSS-lowered female-sperm encounter rates, or triggered an increase in pseudofeces, which could bind sperm in mucus and lead to egestion before fertilization or to juvenile recruitment failure (Österling et al., 2010; Gascho Landis et al., 2013; Gascho Landis \& Stoeckel, 2016).

Regardless of the potential negative impacts of intensive agriculture on mussel abundance and richness, few studies have examined the impacts of these activities on the physiology and growth of individual mussels. Gascho Landis et al. (2013) and Gascho Landis \& Stoeckel (2016) found that while increasing TSS resulted in reduced reproduction, there was no impact on growth rates. Research studies have used growth rates to evaluate changes in food source, inundation frequency, temperature, and release of environmental pollutants (Klunzinger et al., 2014; Negishi et al., 2012, 2014a, b; Fritts et al., 2017). Growth rate has been found to differ between sexes of some mussel species where males often reach a larger maximum size, but this is not true for every species (Haag \& Rypel, 2011). Previous studies also found an inverse relationship between faster growth rates and longevity with faster growing mussels living for a shorter amount of time (Haag \& Rypel, 2011; Sansom et al., 2016; Helama et al., 2017). Haag (2012) has grouped species of mussels into one of three groups that display different life history traits. Equilibrium species have longer life spans and higher ages at maturity coupled with lower levels of fecundity, while opportunistic species have short life spans and lower ages at maturity and high fecundity. Finally, periodic species display moderate to high growth rates and low to intermediate fecundity, life span and age at maturity. It is possible that the differences in growth rates between sexes and species displaying different life history traits may result in certain species being favored in environments that are stressed. The stresses many result in reduced growth or altered reproductive condition in some species. Therefore, the study of growth provides information about the health and 
future of mussel populations as well as a reflection of the environmental history of the ecosystem they live in.

Another indicator of mussel health is glycogen, a form of carbohydrate storage (Stetten \& Stetten, 1960). As the principal carbohydrate storage compound in bivalve mollusks (Gabbott, 1975), glycogen level is related to growth because it indicates how much stored energy is available for metabolism, growth, and reproduction. Various researchers used glycogen levels as a measure of the energetic status of mussels (Naimo et al., 1998; Newton et al., 2001; Beggel et al., 2017). Studies using glycogen as a measure of stress have examined food availability (Patterson et al., 1999), relocation (Chen et al., 2001; Newton et al., 2001), ammonia concentration (Beggel et al., 2017), water discharge (Fritts et al., 2015b) and temperature (Fritts et al., 2015a; Payton et al., 2016; Beggel et al., 2017) as stressors.

Our study area included rivers in Minnesota with varying amounts of agriculture in their basins. The Minnesota River Basin (MRB) is located mainly in southwestern Minnesota. The basin contains a great deal of row crop agriculture (approximately $78 \%$ of land use-Musser \& Kudelka, 2009) although the Conservation Reserve Program has resulted in the conversion of some cropland to wetlands, grassland and open water areas (Musser \& Kudelka, 2009; Yuan et al. 2015). To convert the landscape to highly productive agriculture, major modifications have been made to the landscape to accelerate the removal of water from the land including stream straightening, creation of ditches and extensive subsurface tile drainage network (Musser \& Kudelka, 2009). The accelerated upstream drainage, coupled with increases in precipitation, has resulted in a significant increase in discharge (Novotny \& Stefan, 2007; Johnson et al., 2009a, b; Schottler et al., 2014). This increased discharge is likely responsible for the increased sediment transport within the MRB (Belmont et al., 2011; Schottler et al., 2014). It appears that the most recent sediment input originated from near channel sources such as bank, bluffs and channel incision (Belmont et al., 2011), and not from upland sources such as agricultural field run-off. There is some evidence that TSS concentrations, while high, have declined in the past 3-4 decades (Johnson et al., 2009a, b).

The changes in the MRB due to the draining of wetlands and increased agriculture over the last century as well as more recent changes in hydrology are often cited as the main factors in the decline of the mussel community in this basin. Bright et al. (1990) indicated historically there were 37 mussel species in the MRB with 20 species still present based on their sampling in 1989. An updated survey by the Minnesota Department of Natural Resources (MN DNR) indicated that there were historically 40-41 species (there is uncertainty about Quadrula fragosa) and currently there are 23 species extant (MN DNR, 2007). Hornbach et al. (2019) found that mussel abundance and richness were significantly lower in three rivers in the MRB as compared to a tributary (the Snake River) of the St. Croix River. While there were major impacts in the St. Croix River basin during the late 1800s due to extensive logging (Waters, 1977), the Snake River basin had significantly less land in agriculture than the MRB rivers and it also has minimal urban land. Despite MRB rivers having fewer mussels and fewer species, the maximum sizes of some mussel species inhabiting both river systems were greater in the MRB rivers compared to those found in the Snake River (Hornbach et al., 2019). However, the cause of these differences in size is unknown and could be due to differences in age structure of populations rather than differences in growth rates.

Based on the numerous studies that suggested negative impacts of sediment on mussels, we hypothesized that glycogen levels and growth would be lower in systems with higher sediment loads. Thus, we examined growth, as assessed by external growth rings, and nutritional status, as assessed through tissue glycogen in rivers with varying degrees of sediment load. Second, we hypothesized that females would have lower glycogen concentrations and growth than males since they would likely partition more energy to reproduction. Third, we hypothesized that growth and glycogen concentrations would be related to the life history traits displayed by various species with growth and glycogen concentration being lowest in equilibrium species and greatest in opportunistic species. 


\section{Materials and methods}

Study area

We collected mussels in four rivers in Minnesota (Fig. 1). Three of the rivers are tributaries of the Minnesota River and one is a tributary of the St. Croix River. These river systems have differing amounts of agricultural land and suspended sediment loads (Table 1). We considered the Snake River a "reference" site for the study with minimal agricultural land use with increasing potential land use impacts from the
Chippewa River to the Cottonwood River with the greatest impacts in the Le Sueur River.

Glycogen analysis

We analyzed tissue glycogen content to assess the relative health of mussels among the four river systems. Foot tissue biopsies were taken from 20 to 26 individuals from each of two species Lampsilis cardium and Lasmigona complanata from each river in 2015. All specimens were collected between September $1-5$ to reduce seasonal variation in
Fig. 1 Map of sampling locations in Minnesota. Lcard, Lampsilis cardium; Apli, Amblema plicata; Lcomp, Lasmigona complanata

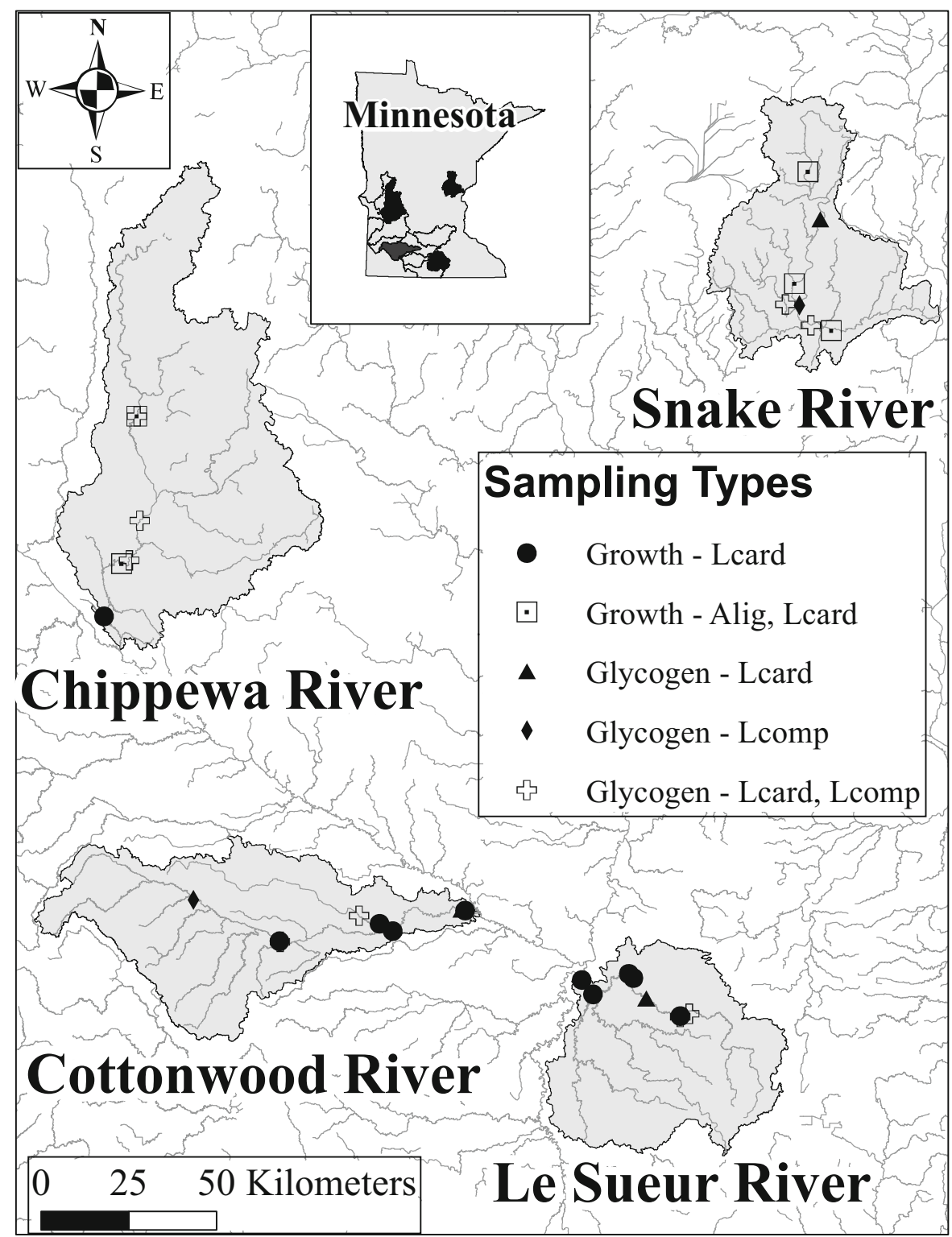


Table 1 Characteristics of rivers sampled

\begin{tabular}{lllll}
\hline & Snake $^{\mathrm{a}, \mathrm{b}}$ & Chippewa $^{\mathrm{c}, \mathrm{d}}$ & Cottonwood $^{\mathrm{c}, \mathrm{e}}$ & Le Sueur, $^{\mathrm{c}, \mathrm{f}}$ \\
\hline Area $\left(\mathrm{km}^{2}\right)$ & 2604 & 5383 & 3403 & 2878 \\
Agriculture $(\%$ of available land) & 8 & 68 & 84 & 84 \\
Suspended sediment load (in millions of $\mathrm{kg})^{\mathrm{g}}$ & 3.1 & $15.9-27.2$ & $34.9-64.2$ & $88.8-163.7$ \\
Mean total suspended solids (mg/L) - $2015^{\mathrm{h}}(N$, standard & $7.3(67$, & $79.8(16$, & 110.7 & $333.8(54$, \\
deviation) & $5.8)$ & $47.6)$ & $(97,137.8)$ & $34.6)$ \\
\hline
\end{tabular}

${ }^{\mathrm{a}}$ Lenz et al. (2003)

bhttps://www.nrcs.usda.gov/Internet/FSE_DOCUMENTS/nrcs142p2_022261.pdf

chttps://works.bepress.com/peter_wilcock/199/

dhttps://www.pca.state.mn.us/sites/default/files/watershed-chippewa.pdf

e https://www.pca.state.mn.us/sites/default/files/watershed-cottonwood.pdf

fhttps://www.pca.state.mn.us/sites/default/files/watershed-blueearth.pdf

${ }^{g}$ Annual Load for Snake, 1999; sampling during March-August 1996 were used to calculate the lower values for the Chippewa, Cottonwood and Le Sueur and the average over 2005-2007 was used for higher values

${ }^{\mathrm{h}}$ Data from https://www.pca.state.mn.us/data/environmental-quality-information-system-equis

glycogen content influencing the results. We chose these two species because they were found in all four rivers and because they represent two different subfamilies of unionoids with different life history traits (L. cardium - a member of the subfamily Ambleminae (Williams et al., 2017) with a periodic life history; L. complanata-a member of the subfamily Unioninae (Williams et al., 2017) with an opportunistic life history.) Glycogen concentration was assessed using techniques outlined in Naimo et al. (1998) by the U.S. Geological Survey (USGS) laboratory in La Crosse, WI. We compared the glycogen concentration (in $\mathrm{mg} / \mathrm{g}$ wet weight) between species and among rivers using a two-way analysis of variance. No transformation of data was needed since the data were normally distributed (Shapiro-Wilk W test). Because L. cardium is sexually dimorphic, we examined the difference in glycogen concentration between males and females, again using a two-way analysis of variance with river, sex and their interaction as independent variables. Finally, because some female $L$. cardium were gravid we compared glycogen concentration among rivers for males only to control for the confounding factor of reproductive condition.

Mussel growth

We followed the methods described in Hornbach et al. (2014) to assess mussel growth. We measured external shell rings to assess mussel growth of L. cardium. We collected approximately 25 individuals of $L$. cardium from each of three areas (upper, middle and lower reaches) of each river (Fig. 1). We also assessed growth of 24 Amblema plicata in the Chippewa and Snake rivers. While we would have preferred sampling L. complanata for growth as we had for glycogen in all four rivers, growth was assessed in 2017 while glycogen levels were assessed in 2015 and the small number of $L$. complanata occurring in the rivers made this infeasible. We measured the maximum anterior to posterior length of presumptive annuli approximately parallel to the shell hinge (see Fig. 2 in Zieritz \& Aldridge, 2009) with a caliper to the nearest $1 \mathrm{~mm}$ and made note of whether the umbos were eroded. While internal ring counts have been used to estimate mussel age (Haag \& Commens-Carson, 2008), this method requires sacrificing animals and we did not have permission to do this. Sansom et al. (2013) found that despite differences in internal and external age estimates, growth estimates were consistently in agreement between the two methods. Since determining age from growth lines, especially external growth lines, is controversial (Downing et al., 1992), we focused on assessing growth over rest intervals and not age. Even when assessing growth with external growth lines there are still some issues since disturbances may result in the production of external growth lines. Morris \& Corkum (1999) suggest more rest lines are 
found on shells in areas with more disturbances, in their case rivers with grassy banks verses those with forested banks.

We used Ford-Walford plots $\left[L_{t+1}=L_{\infty}(1-\right.$ $\left.e^{-K}\right)+L_{t} e^{-K}$ (Anthony et al., 2001)] to estimate parameters of the von Bertalanffy model of growth $\left[L_{t}=L_{\infty}\left(1-e^{-K\left(t-t_{0}\right)}\right)\right]$ where $L_{t}$ is length $(\mathrm{mm})$ at time $t$ (age), $L_{\infty}$ is length (mm) at time infinity (the predicted mean maximum length for the population), $K$ is a growth constant that describes the rate at which $L_{\infty}$ is attained, $t$ is age (years) and $t_{0}$ is the time at which length $=0$ (Haag \& Rypel, 2011). Since we cannot be sure that the external rings we measured were annual, the $t$ in our analysis is the time between the ring depositions. We calculated $K$ and $L_{\infty}$ using values for $L_{t}$ and $L_{t+1}$ pooled for all individuals in each of the three areas from each river and using ANOVA tested whether location (river), sex and their interaction varied for these two variables. While there are some difficulties in estimating parameters of the von Bertalanffy models (Hua et al., 2016) they remain useful for comparing growth in mussel populations.

Since there can be an interaction between $K$ and $L_{\infty}$, it is often difficult to interpret these values. In this study an analysis of covariance (ANCOVA) with $L_{t+1}$ as the dependent variable, location as the independent variable and $L_{t}$ as the covariable allows for the examination of the differences among locations and sexes in $K$ and $L_{\infty}$. We conducted a similar ANCOVA to examine differences in $K$ and $L_{\infty}$ between A. plicata and $L$. cardium from the Snake and Chippewa Rivers. Using ANCOVA, we also examined the growth interval between adjacent external rings and determined whether these growth intervals differed among populations and sexes, adjusting for the size of the organism (the starting length of the external ring for each growth interval). These growth intervals were log-transformed before analyses.

\section{Water quality}

Water quality data were queried from the Minnesota Pollution Control Agency's (MNPCA) environmental monitoring database (https://www.pca.state.mn.us/ data/environmental-quality-information-system-equis) for sites near those where we sampled mussels. We were able to obtain data for TSS, ammonia as nitrogen $(\mathrm{N})$, nitrate-nitrite $\mathrm{N}$, total phosphorus $(\mathrm{P})$, chlorophyll a (chl a) and water temperature. Since the water quality data were not always collected in the same year for all rivers, we chose only those years when data were available for all rivers. For water temperature, we used data from 2009 to 2015 for May-September. All of the rivers had data available for those years and months. We compared the water quality parameters for the four rivers using a mixed model ANOVA with year as a random variable and river as the fixed effect. For water temperature both year and month were used as random variables.

All statistical analyses were conducted with JMP Pro® version 13 (SAS Institute Inc., Cary, NC).

\section{Results}

\section{Glycogen}

The glycogen concentration of mussels varied significantly between species and among rivers (Fig. 2two-way ANOVA; Location $F_{3,183}=91.4$, $P<0.0001$; Species $F_{1,183}=15.4, P=0.0001$; Location*Species $\left.F_{3,183}=3.2, P=0.03\right)$. The glycogen concentration of $L$. complanata was greater than $L$. cardium, and glycogen concentration increased with increasing agricultural impact in the basin. The significant interaction term and a post hoc Tukey test indicated that in the Snake and Chippewa Rivers glycogen content was not significantly different among species while in the Cottonwood and Le Sueur rivers the glycogen content was significantly greater in L. complanata than L. cardium (Fig. 2). There was no significant difference in glycogen concentration between sexes for $L$. cardium (two-way ANOVA; Location $\mathrm{F}_{3,90}=670, P<0.0001 ;$ Sex $\mathrm{F}_{1,90}=2.8$, $P=0.6$; Location*Sex $\mathrm{F}_{3,90}=9.0, P=0.8$ ). However, this is complicated by the fact that all of the females collected from the Chippewa River were gravid, while none of the females from the Snake River were gravid. In the Cottonwood and Le Sueur Rivers, $78 \%$ and $83 \%$ of females were gravid, respectively. There was nearly a significant difference between these groups with gravid individuals having higher amounts of glycogen with no significant interaction between location and gravidity (two-way ANOVA; Location $F_{1,14}=133.1 P=0.0015$; Gravidity $F_{1,14}=4.5, \quad P=0.06 ; \quad$ Location*Gravidity 


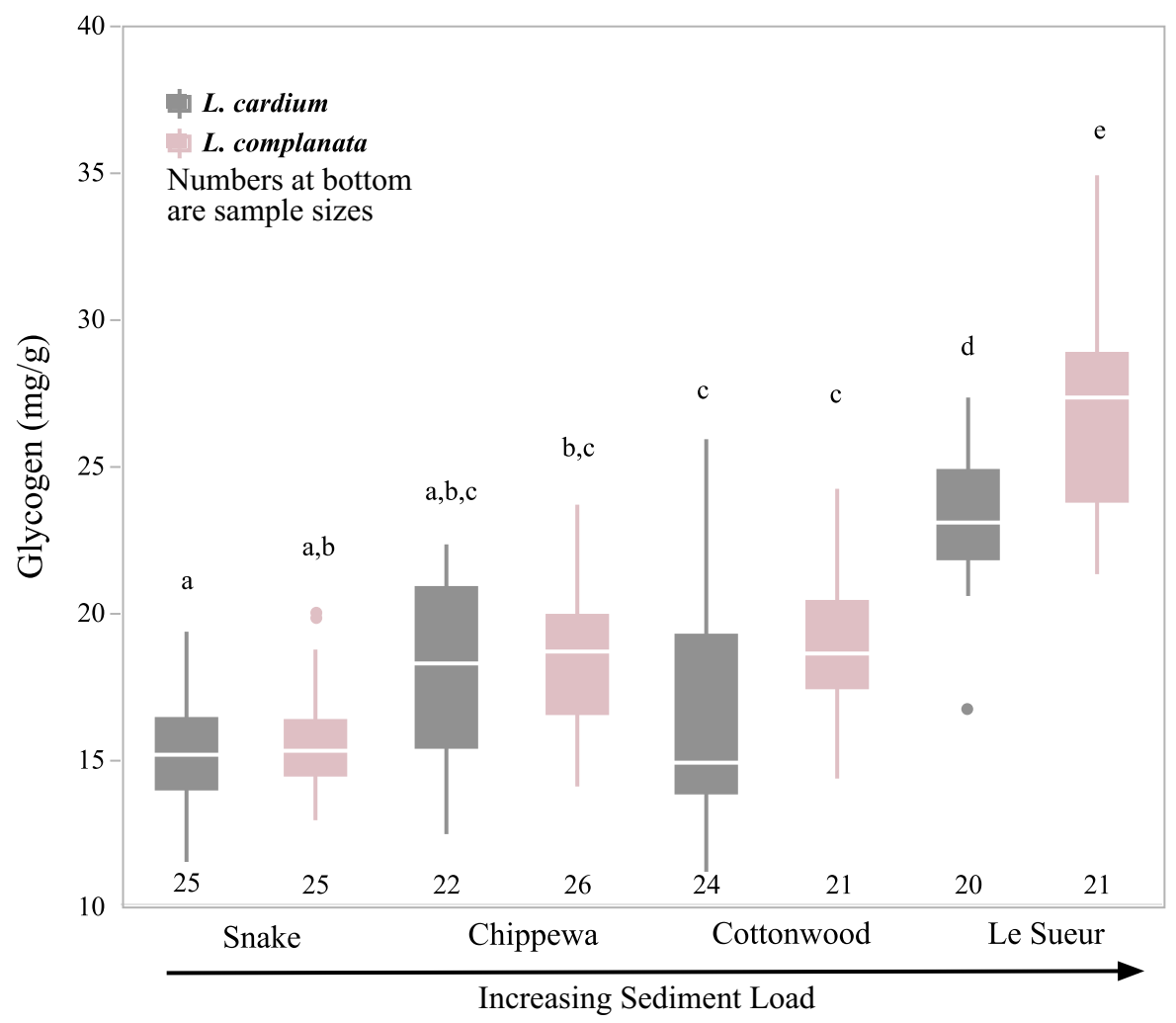

Fig. 2 Box plots of glycogen concentration (in $\mathrm{mg} / \mathrm{g}$ wet weight) of two species of mussels, Lampsilis cardium and Lasmigona complanata from four rivers in Minnesota.

$\left.F_{1,14}=0.1, P=0.7\right)$. In the Chippewa River, even though all females were gravid, there was no significant difference in glycogen concentration between the sexes ( $t$ test; $t_{8}=0.13, P=0.9$ ). This makes disentangling the effect of river and reproductive status difficult. Thus, we conducted an analysis of glycogen concentration of males only (14-19 males per river) and found that the trend of increasing glycogen concentration with increasing agriculture followed the same trend as for all $L$. cardium that was seen in Fig. 2 (One-way ANOVA for males; Location $\left.F_{3,64}=17.2, P<0.0001\right)$.

\section{Mussel Growth}

Lampsilis cardium grew fastest in the Le Sueur River with slower growth in the Cottonwood, Chippewa and Snake rivers, respectively. There were a number of analyses that supported this conclusion. An analysis of covariance with $L_{t+1}$ as the dependent variable, location and sex as independent variables, $L_{t}$ as the
Suspended sediment loads increase from the Snake through the Le Sueur River. Bars with the same letters are not significantly different

covariable and their interactions showed that there were significant influences of all the independent variables and the covariable as well as most interactions on the dependent variable (Fig. 3; Table 2). Figure 3 also shows that there were very few individuals from the Snake River with initial rest lines of length $<50 \mathrm{~mm}$. This was due to most of the individuals in the Snake River having eroded umbos. To examine whether this fact influenced our assessment of growth, we re-ran the ANCOVA outlined above for individuals with an $L_{t} \geq 50 \mathrm{~mm}$. The results of this ANCOVA were essentially the same as those given in Table 2. We also found a good deal of variation in the value of $L_{t+1}$ when $L_{t}=0(6-55 \mathrm{~mm}$; Fig. 3). These were only for individuals found in the MRB. We conducted an ANOVA with values of $L_{t+1}$ when $L_{t}=0$ as the dependent variable and river, sex and their interaction as independent variables. There was a significant difference between rivers $\left(F_{2,92}=7.4, P=0.001\right)$ but no difference between sexes or the interaction of sex and river (Sex 


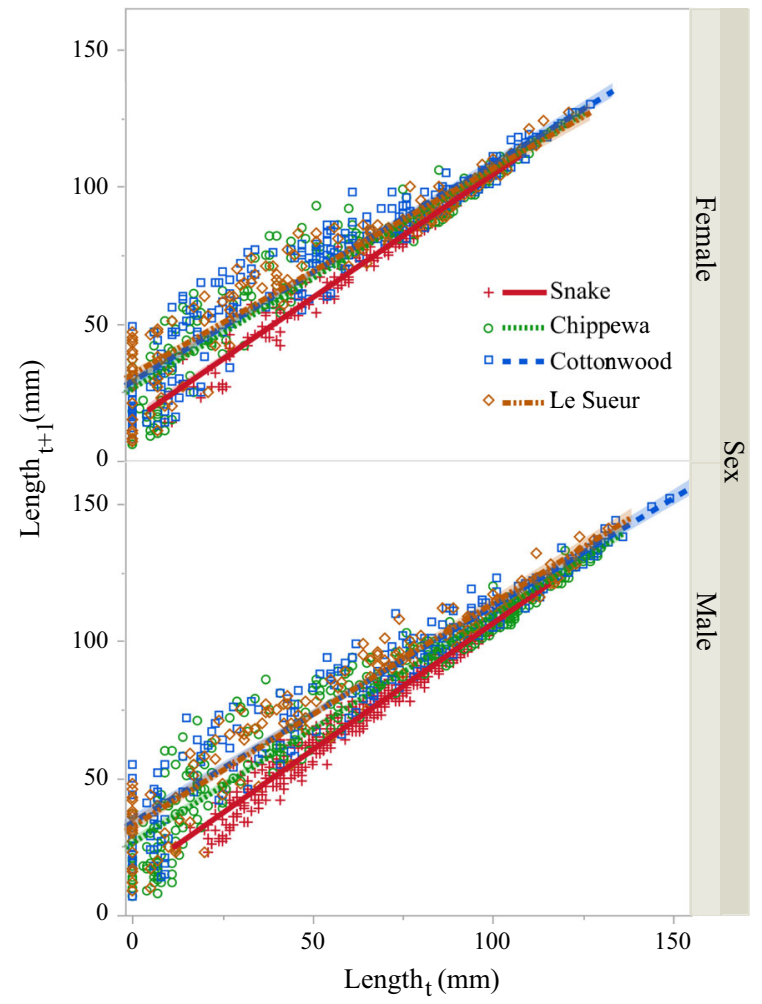

Fig. 3 Ford-Walford plots for male and female Lampsilis cardium from four rivers in Minnesota, where $L_{t+1}$ is the length at one time interval greater than $L_{t}$. Suspended sediment loads decrease in the following order: Le Sueur $>$ Cottonwood $>$ Chippewa $>$ Snake

$F_{1,92}=0.1, P=0.7$; Sex*River $F_{2,92}=1.6, P=0.2$ ). A post hoc Tukey test indicated that the average $L_{t+1}$ was greatest for the Le Sueur River $(30.8 \mathrm{~mm})$, followed by the Cottonwood River $(24.5 \mathrm{~mm})$ and then the Chippewa River (18.9 mm).

A similar analysis using $\ln$ (growth interval) as determined as the difference in length between adjacent external growth lines as the dependent variable again showed that the independent variables and the covariable as well as most interactions were significant (Fig. 4, Table 3). A post hoc Tukey test showed that growth intervals followed the trend Le Sueur River $\geq$ Cottonwood River $>$ Chippewa River $>$ Snake River. A similar analysis for A. plicata showed that growth intervals were also greater in the Chippewa as compared to the Snake River (Fig. 5). $L$. cardium had larger growth intervals than A. plicata (Table 4-Two-way ANCOVA) in both the Snake and Chippewa Rivers and the significant interaction term between river and species indicated that while growth intervals for large L. cardium converged for the Snake and Chippewa, large A. plicata in the Snake continued to grow larger than in the Chippewa (Fig. 5).

We also calculated values of $K$ and $L_{\infty}$ for the three areas within each river. For $L$. cardium there were significant differences in $K$ among locations and sexes but there was not a significant interaction term (Table 5-Two-way ANOVA: Location $F_{3,23}=5.8$, $P=0.007$; Sex $F_{1,23}=5.2, P=0.04$; Location*Sex $\left.F_{3,23}=1.4, P=0.3\right)$. There was a significant difference in $L_{\infty}$ between sexes, with males larger than females, but no differences among locations or a significant interaction (Table 5-Two-way ANOVA: Location $F_{3,23}=0.03, P=0.99$; Sex $F_{1,23}=11.2$, $P=0.004$; Location*Sex $F_{3,23}=0.6, P=0.6$ ). For $A$. plicata $K$ was significantly greater for the Chippewa population than the Snake population but there was no significant difference between $L_{\infty}$ (Table 5- $t$ test: $K-t_{3.1}=3.8, P=0.03 ; L_{\infty}-t_{2.9}=0.8, P=0.5$ ).

Water quality

There were significant differences in water temperature among the rivers (Fig. 6-Mixed Model
Table 2 Factors influencing growth of Lampsilis cardium and Amblema plicata as assessed using the FordWalford plots $\left(L_{t}\right.$ vs. $\left.L_{t+1}\right)$

\begin{tabular}{lccccc}
\hline Source & \multicolumn{2}{l}{ Lampsilis cardium } & & \multicolumn{2}{l}{ Amblema plicata } \\
\cline { 2 - 3 } & $F(d f)$ & Probability & & $F(d f)$ & Probability \\
\hline River & $127.7(3,1591)$ & $<0.0001$ & & $653.5(1,1590)$ & $<0.0001$ \\
Sex & $52.1(1,1591)$ & $<0.0001$ & & - & - \\
River*Sex & $6.9(3,1591)$ & $<0.0001$ & & - & - \\
Length & $13926(1,1591)$ & $<0.0001$ & & $130558(1,1590)$ & $<0.0001$ \\
River*Length $_{t}$ & $13.8(3,1591)$ & $<0.0001$ & & $162.2(1,1590)$ & $<0.0001$ \\
Sex*Length $_{\mathrm{t}}$ & $3.8(1,1591)$ & 0.05 & & - & - \\
River*Sex*Length $_{\mathrm{t}}$ & $2.4(1,1591)$ & 0.07 & & - & - \\
\hline
\end{tabular}




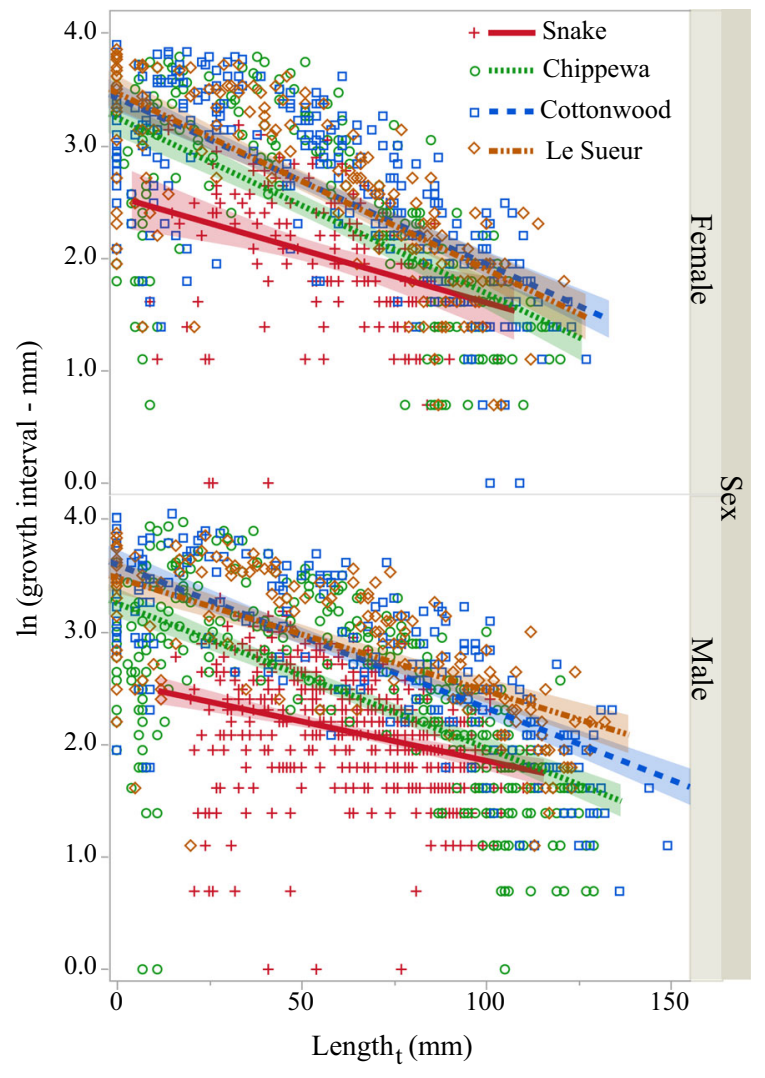

Fig. 4 Changes in male and female Lampsilis cardium growth intervals (natural $\log$ of the growth interval) with size (shell length) among four rivers in Minnesota. Suspended sediment loads decrease in the following order: Le Sueur $>$ Cottonwood $>$ Chippewa $>$ Snake. Shaded areas are $95 \%$ confidence limits

ANOVA: $\left.F_{3,1687}=126.9, P<0.0001\right)$. A Tukey post hoc test showed that the Snake River was significantly cooler than any of the MRB rivers. There were also significant differences among rivers in a number of water quality parameters (Fig. 7): TSS (Mixed Model ANOVA: $\left.F_{3,3203}=91.4, P<0.0001\right)$, nitrate-nitrite

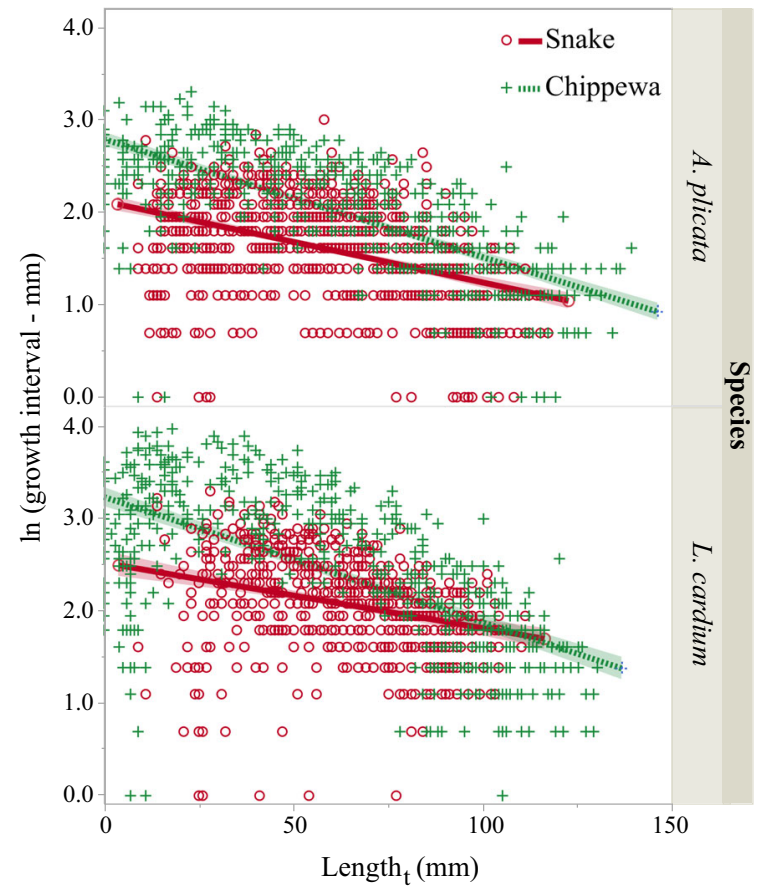

Fig. 5 Change in Amblema plicata and Lampsilis cardium growth intervals (natural log of the growth interval) with size (shell length) between two rivers in Minnesota. Suspended sediment loads are greater in the Chippewa than the Snake River. Shaded areas are $95 \%$ confidence limits

$\mathrm{N}$ (Mixed Model ANOVA: $\mathrm{F}_{3,2405}=382.3$, $P<0.0001$ ), total phosphorus (Mixed Model ANOVA: $\left.F_{3,3203}=91.4, P<0.0001\right)$, and chl a (Mixed Model ANOVA: $F_{3,56}=5.6, P<0.002$ ). Generally, the Snake River had lower levels of these constituents compared to the rivers in the MRB. In addition, levels of ammonia- $\mathrm{N}$ varied among rivers with the Le Sueur having significantly higher levels than the other rivers (Fig. 8, $F_{3,498}=14.6$, $P<0.0001)$.
Table 3 Factors influencing growth of Lampsilis cardium and Amblema plicata as assessed ln (growth rate) based on increases in size between external growth rings

\begin{tabular}{lccccc}
\hline Source & \multicolumn{2}{l}{ Lampsilis cardium } & & \multicolumn{2}{l}{ Amblema plicata } \\
\cline { 2 - 3 } \cline { 5 - 6 } & $F(d f)$ & Probability & & $F(d f)$ & Probability \\
\hline River & $101.2(3,1591)$ & $<0.0001$ & & $87.5(1,1586)$ & $<0.0001$ \\
Sex & $64.5(1,1591)$ & $<0.0001$ & & - & - \\
River*Sex & $4.2(3,1591)$ & 0.006 & & - & - \\
Length & $652.5(1,1591)$ & $<0.0001$ & & $938.7(1,1586)$ & $<0.0001$ \\
River*Length $_{\mathrm{t}}$ & $5.6(3,1591)$ & 0.0008 & & $46.3(1,1586)$ & $<0.0001$ \\
Sex*Length $_{\mathrm{t}}$ & $9.2(1,1591)$ & 0.0024 & & - & - \\
River*Sex*Length $_{\mathrm{t}}$ & $1.5(1,1591)$ & 0.2 & - & - \\
\hline
\end{tabular}


Table 4 Comparison of growth in Lampsilis cardium and Amblema plicata as assessed ln (growth interval) based on increases in size between external growth rings

\begin{tabular}{lrc}
\hline Source & \multicolumn{1}{c}{$F(d f)$} & Probability \\
\hline River & $307.7(1,2553)$ & $<0.0001$ \\
Species & $445.0(1,2553)$ & $<0.0001$ \\
River*Species & $6.8(1,2553)$ & 0.009 \\
Length $_{\mathrm{t}}$ & $813.1(1,2553)$ & $<0.0001$ \\
River*Length $_{\mathrm{t}}$ & $51.8(1,2553)$ & $<0.0001$ \\
Species*Length $_{\mathrm{t}}$ & $0.6(1,2553)$ & 0.4 \\
River*Species*Length $_{\mathrm{t}}$ & $3.2(1,2553)$ & 0.08 \\
\hline
\end{tabular}

\section{Discussion}

Measured declines in mussel populations over the past century in many rivers across the U.S. have been attributed to a variety of causes, including increases in water velocity, shear stress and suspended sediment loads. These factors have been hypothesized to interfere with filtration, fertilization, recruitment and establishment of juvenile mussels in several studies (Reid et al., 2012; Gascho Landis et al., 2013; French \& Ackerman, 2014; Gascho Landis \& Stoeckel, 2016; Hansen et al., 2016; Stoeckel \& Geist, 2016; Hornbach et al., 2019). However, our results suggest highsuspended sediment loads may not affect mussel glycogen content or growth in a negative way. Therefore, declining population size may not be correlated with growth or condition of adult mussels found in these rivers. Despite sex and species differences, the variability across the river systems in this study was a constant determinant of growth suggesting

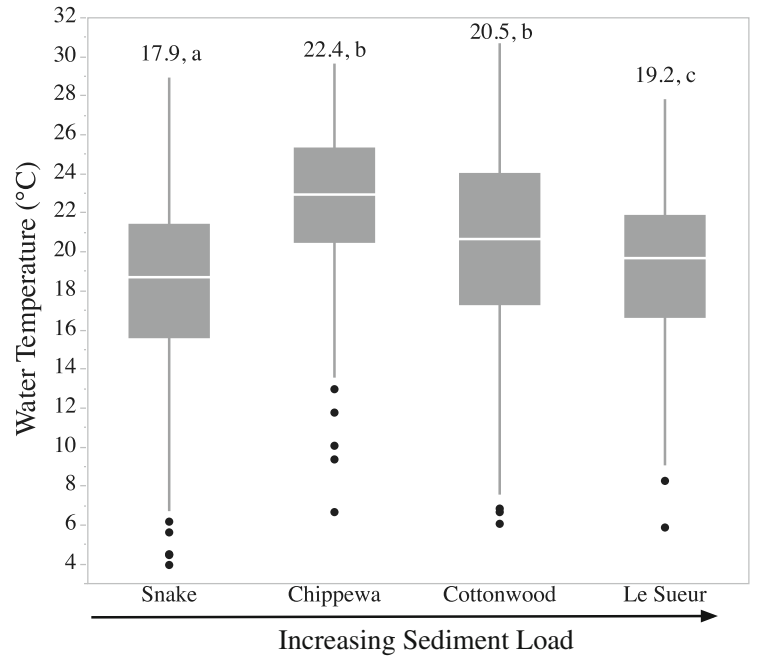

Fig. 6 Box plots of water temperature from four rivers in Minnesota averaged over May-September for 2009-2015. The number above the bar is the overall average temperature. Bars with the same letters are not significantly different

that environmental conditions (nutrients, food availability and temperature) are driving the significant differences seen in growth and glycogen level. However, the equilibrium species A. plicata, was not found often in the rivers with the highest sediment loads suggesting species with this life history strategy may be disproportionately affected (Hornbach et al., 2019). Many environmental factors (e.g. geology, other types of land use besides agriculture, regulation by dams, etc.) vary among the rivers investigated in this study and each could be responsible for the discrepancies in growth seen in the results. However, it is difficult to separate these conditions since they could not be controlled for. Most of the variability across rivers is

Table 5 Mean values of $K$ and $L_{\infty}$ from the von Bertalanffy equation estimated from the Ford-Walford plot for $L$. cardium and $A$. plicata

\begin{tabular}{|c|c|c|c|c|c|c|}
\hline \multirow[t]{3}{*}{ River } & \multicolumn{4}{|c|}{ Lampsilis cardium } & \multicolumn{2}{|c|}{ Amblema plicata } \\
\hline & \multicolumn{2}{|l|}{$K$ value } & \multicolumn{2}{|l|}{$L_{\infty}(\mathrm{mm})$} & \multirow[t]{2}{*}{$K$ value } & \multirow{2}{*}{$L_{\infty}(\mathrm{mm})$} \\
\hline & Female & Male & Female & Male & & \\
\hline Snake & $0.18(0.04)$ & $0.14(0.06)$ & $116.1(16.4)$ & $151.9(43.8)$ & $0.06(0.01)$ & $163.5(10.1)$ \\
\hline Chippewa & $0.39(0.08)$ & $0.29(0.15)$ & $114.6(6.9)$ & $153.2(48.8)$ & $0.11(0.02)$ & $152.2(20.9)$ \\
\hline Cottonwood & $0.39(0.02)$ & $0.35(0.06)$ & $119.7(5.6)$ & $139.5(1.7)$ & - & - \\
\hline Le Sueur & $0.62(0.28)$ & $0.32(0.12)$ & $99.7(21.4)$ & $163(39.3)$ & - & - \\
\hline
\end{tabular}

Values in parentheses are standard deviations 


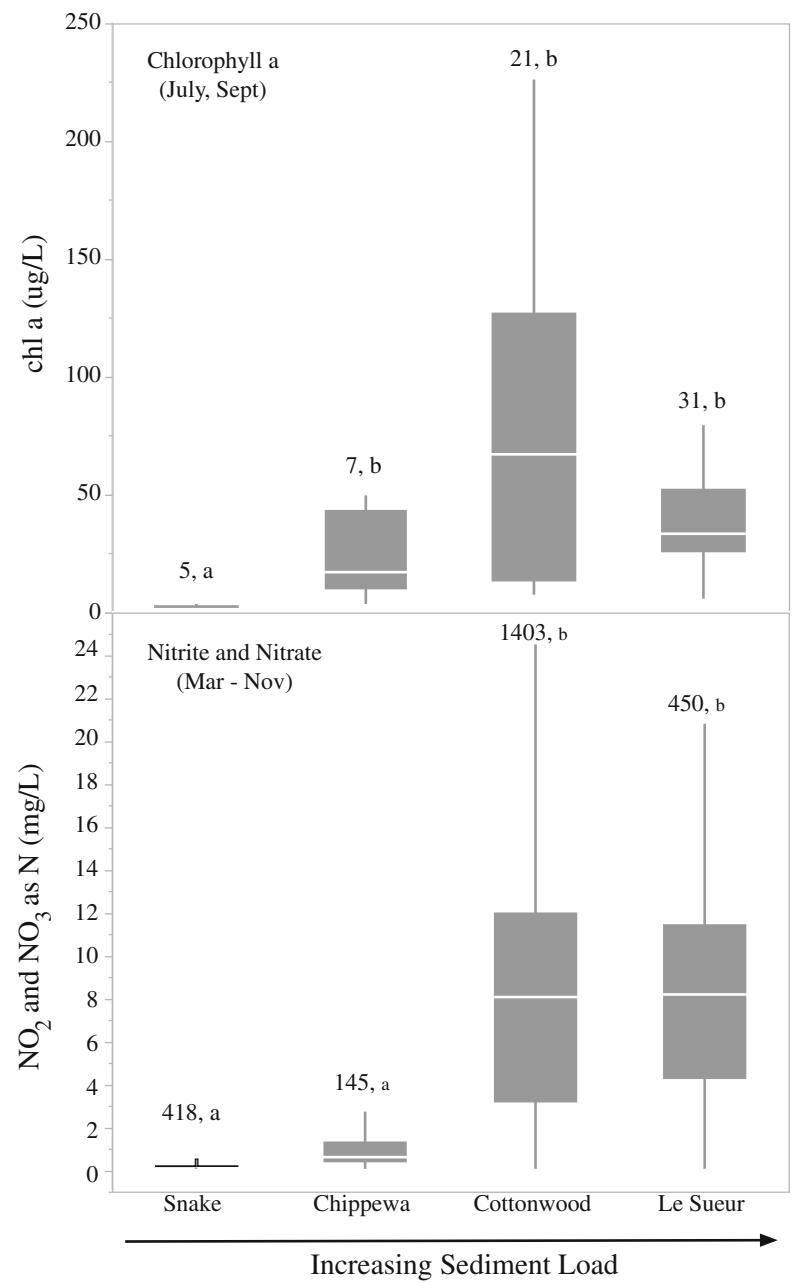

Fig. 7 Box plots of chlorophyll a, nitrite and nitrate, total phosphorus and total suspended solids for four rivers in Minnesota. The numbers above the bars are the sample sizes

likely influenced by surrounding land use, hydrology, and latitude as well as the underlying geology.

We hypothesized that glycogen levels in mussels would be lower in areas with greater sediment loads due to the stress-increased loads would likely place on them. Fritts et al. (2015b) found that glycogen levels declined with increasing discharge levels, attributing this to a cessation of feeding during high-flow events likely due to increased levels of suspended solids. Tuttle-Raycraft et al. (2017) found that higher suspended solids (in this case a mix of organic and inorganic suspended solids) reduced feeding in mussels. Gustafson et al. (2005) found no significant difference in glycogen levels for Elliptio complanata from agricultural areas compared to forested areas

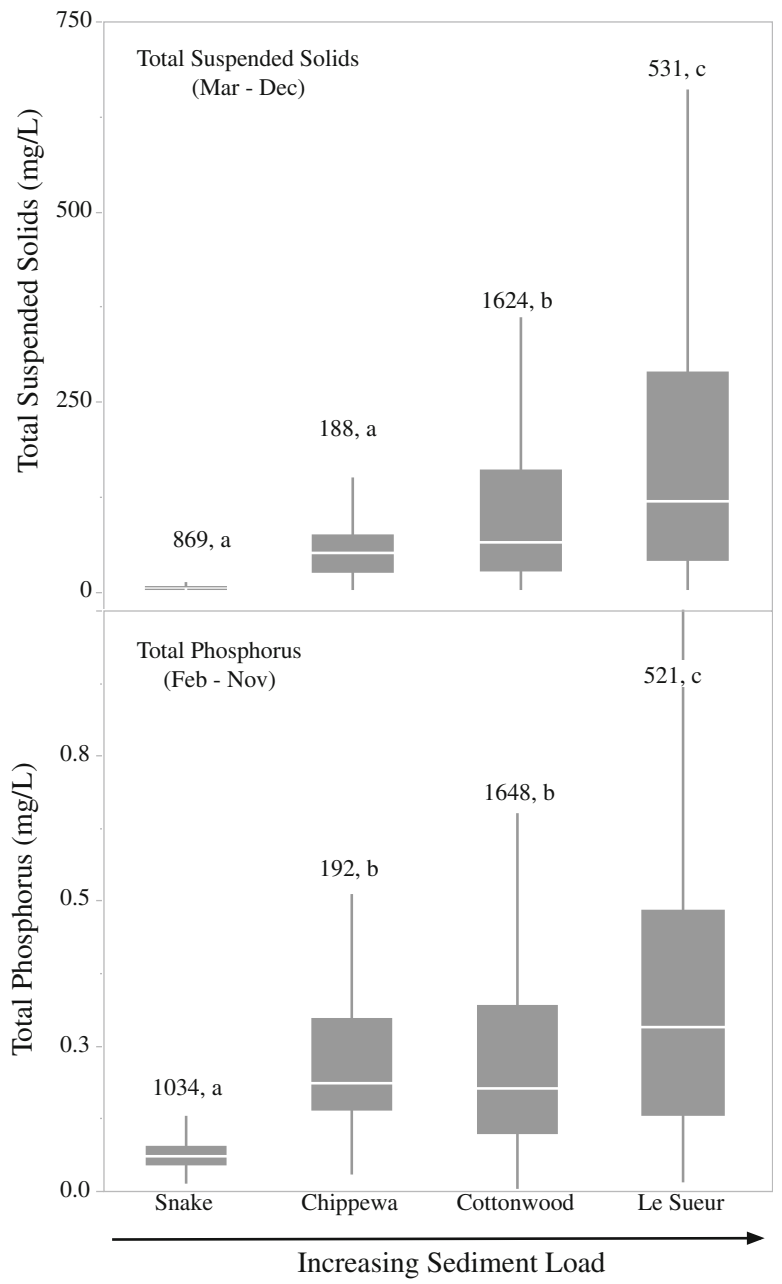

and bars with the same letter are not significantly different. Suspended sediment loads decrease in the following order: Le Sueur $>$ Cottonwood $>$ Chippewa $>$ Snake

although hemolymph glucose levels were significantly higher in forested sites. Despite the potential stress imposed by high levels of suspended solids in the rivers of the MRB we found higher glycogen levels in basins with higher amounts of agriculture and suspended solids for both species we examined. A number of studies showed that other types of stressors can also influence glycogen levels. Haag et al. (1993), Baker \& Hornbach (2000) and McGoldrick et al. (2009) found that unionid mussels infested with zebra mussels had lower glycogen or carbohydrate levels than non-infested mussels. Temperature stress was associated with decreases in glycogen concentration in Elliptio crassidens, but not in Villosa vibex (Fritts et al., 2015a) at temperatures that were generally 


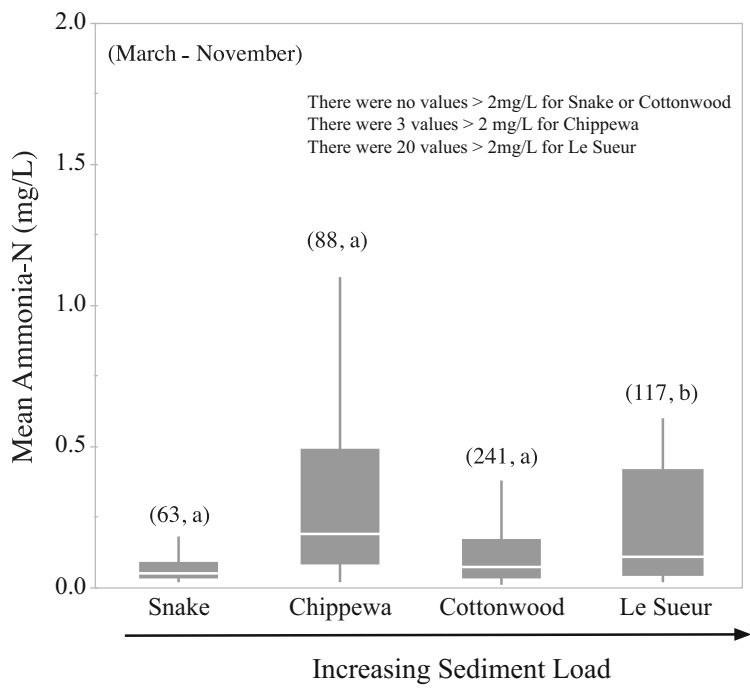

Fig. 8 Box plots of ammonia-N levels from four rivers in Minnesota. The numbers above the bars are the sample sizes and bars with the same letter are not significantly different. Suspended sediment loads decrease in the following order: Le Sueur $>$ Cottonwood $>$ Chippewa $>$ Snake

higher $\left(25,30\right.$ and $\left.35^{\circ} \mathrm{C}\right)$ than averages at our study sites $\left(18-22^{\circ} \mathrm{C}\right)$. Payton et al. (2016) found differing responses in glycogen to increased temperature (ponds kept at $\sim 2.5^{\circ} \mathrm{C}$ warmer than ambient temperatures). While there was no difference between species under ambient temperatures, Villosa lienosa (a thermally tolerant species) showed an increase in glycogen levels with chronic warming while, V. nebulosa (a thermally sensitive species) showed no change in glycogen with warming. They suggested that in the thermally tolerant species the increase in glycogen might be due to a decline in the metabolic breakdown of stored glycogen. In our study, temperature was lowest in the Snake River and higher in the rivers of the MRB. Lampsilis cardium is considered a thermally sensitive species (Waller et al., 1999; Spooner \& Vaughn, 2008) and juvenile L. complanata have lower thermal tolerance than a number of other species (Ganser et al., 2013) and thus the higher levels of glycogen in the warmer streams do not conform to the results of Fritts et al. (2015a). Patterson et al. (1999) found that two species of mussels held in quarantine without food had lower glycogen levels than those held with food. Similarly, Naimo \& Monroe (1999) found that mussels held in a pond had $80 \%$ lower glycogen in foot tissue compared to mussels from their native environment. The levels of glycogen found in our study were of the same order of magnitude as levels found in other studies (Table 6).

In addition to differences in glycogen levels among river systems, we found that the glycogen concentration of $L$. complanata was greater than that of $L$. cardium. Lasmigona complanata displays opportunistic life history traits while $L$. cardium displays periodic life history traits (moderate to high growth rates, low to intermediate fecundity, life span and age at maturity-Haag, 2012). One might expect opportunistic species to have lower glycogen concentration because of the higher growth rates and reproductive output. However, this was not the case in our study mainly due to the high-glycogen concentration of $L$. complanata in the Le Sueur River that had the highest degree of agricultural impact (i.e. high levels of $\mathrm{NO}_{2}-$ $\mathrm{NO}_{3}$, ammonia-N, TSS and $\mathrm{P}$ ).

While the differences in life history traits appear to influence glycogen levels it is also possible that reproductive condition within a species may affect energy stores. Past studies showed the relationship between glycogen concentration and reproductive condition in freshwater mussels is variable. Gustafson et al. (2005) found hemolymph glycogen values were lower in E. complanata that were gravid. However, Baker \& Hornbach (2001) found that the carbohydrate concentration did not differ among brooding and nonbrooding Actinonaias ligamentina. Payton et al. (2016) suggest that glycogen stores might be allocated to reproduction rather than growth in a thermally tolerant species when challenged at high temperatures indicating there may not necessarily be a link between glycogen stores and measures of growth. In our study we found that there was no difference in glycogen concentration between males and females and no difference in the one river where we could compare brooding $L$. cardium females with males supporting a number of studies that indicated no difference in glycogen content and reproductive condition or sex.

We examined growth in addition to glycogen concentration in our study. Again, we hypothesized that increasing sediment loads associated with greater amounts of agriculture would lead to reduced growth. Contrary to our expectations, we found greater growth in areas with greater amount of agriculture, possibly due to increased nutrients ( $\mathrm{N}$ and $\mathrm{P}$ in MRB rivers) leading to increased food availability (increase chlorophyll a), along with warmer temperatures in the MRB rivers. Morris \& Corkum (1999) attributed higher 
Table 6 Comparison of glycogen concentration reported by a variety of authors

\begin{tabular}{|c|c|c|}
\hline Study & Species & Mean glycogen content (mg/g wet weight) \\
\hline This & Lampsilis cardium-male & $\begin{array}{l}\text { 15.1-Snake R. } \\
\text { 18.2-Chippewa R. } \\
\text { 17.1-Cottonwood R. } \\
\text { 23.1-Le Sueur R. }\end{array}$ \\
\hline This & Lampsilis cardium-female & $\begin{array}{l}\text { 15.0-Snake R. } \\
\text { 18.0-Chippewa R. } \\
\text { 15.6-Cottonwood R. } \\
\text { 23.3-Le Sueur R. }\end{array}$ \\
\hline This & Lasmigona complanata & $\begin{array}{l}\text { 15.7-Snake R. } \\
\text { 18.3-Chippewa R. } \\
\text { 18.9-Cottonwood R. } \\
\text { 26.6-Le Sueur R. }\end{array}$ \\
\hline Haag et al. (1993) & Amblema plicata & $0.6-10.3^{\mathrm{a}}$ \\
\hline Haag et al. (1993) & Lampsilis radiata & $0.05-7.6^{\mathrm{a}}$ \\
\hline Naimo and Monroe (1999) & Amblema plicata & 22.2 \\
\hline Patterson et al. (1999) & Amblema plicata & $8.1-9.4^{\mathrm{b}}$ \\
\hline Patterson et al. (1999) & Quadrula pustulosa & $6.2-7.9^{\mathrm{b}}$ \\
\hline Baker \& Hornbach (2000) & Amblema plicata & $\begin{array}{l}25.0 \text { - non zebra mussel encrusted } \\
\text { 12.5-zebra mussel encrusted }\end{array}$ \\
\hline Monroe \& Newton (2001) & Amblema plicata & $15.7-30.6^{\mathrm{c}, \mathrm{d}}$ \\
\hline Gustafson et al. (2005) & Elliptio complanata & $\begin{array}{l}\text { 11.4- } \text { non-gravid }^{\mathrm{c}} \\
15.8 \text { - } \text { gravid }^{\mathrm{c}} \\
17.7 \text { - agricultural area } \\
18.8 \text { - forested area }\end{array}$ \\
\hline McGoldrick et al. (2009) & Lampsilis siliquoidea & $\begin{array}{l}15.0 \text { - non zebra mussel encrusted } \\
7.3 \text {-zebra mussel encrusted }\end{array}$ \\
\hline Fritts et al. (2015a) & Elliptio crassidens & $67.4-81.8^{\mathrm{e}}$ \\
\hline Fritts et al. (2015a) & Villosa vibex & $49.6-83.0^{\mathrm{e}}$ \\
\hline
\end{tabular}

${ }^{\mathrm{a}}$ Varies based on location

${ }^{\mathrm{b}}$ Range for 2 years; based on wet preserved weight

${ }^{c}$ Dry weight to wet weight conversion of $83.4 \%$-Naimo \& Monroe (1999)

${ }^{\mathrm{d}}$ Varies based on season-riverine mussels only

${ }^{\mathrm{e}}$ Varies based on temperature

growth in rivers with grassy riparian vegetation compared to those with forested banks to increased $\mathrm{N}$ levels and warmer temperatures. They also indicated if there were more rest lines associated with greater disturbances in the grass-lined areas then their calculation of growth rates was conservative. The assessment of growth we conducted combined measurements taken throughout each river (lower, middle and upper stretches). Thus, while there may be differences in rest periods within a river, our analysis would include this variability. However, differences in rest periods among rivers could influence our findings. All of our rivers freeze in the winter providing at least one annual rest line. It seems more likely that additional rest periods would be found in the MRB rivers since they have more periods of high temperature, greater TSS, and higher levels of ammonia. If this was the case, and the number of MRB rest periods is higher, then actual rates of growth in the MRB rivers would be even greater. Strayer \& Fetterman (1999) 
also suggested that increased $\mathrm{N}$ and $\mathrm{P}$ levels led to an increase in sizes for two species of mussels sampled 30 years apart. However, increased nutrients do not always lead to increased growth. Bartsch et al. (2017) suggested increased $\mathrm{N}$ and $\mathrm{P}$ led to reduced growth in Lampsilis siliquoidea because of a shift from smaller green algae to larger blue-green algae resulting in reduced feeding and growth. Despite the impact on growth in L. siliquoidea, there was no effect on growth of $L$. cardium.

Food availability has also been implicated in influencing growth rates. Haag \& Rypel (2011), citing a number of studies, indicated that mussels grow more rapidly in rivers and lakes that are productive and that food limitation can result in decreased shell size and growth rates. Fritts et al. (2017) found that mussel size increased in the US over the past 1000 years, and they attributed this to human impacts including increased nutrients from agriculture and municipal inputs and the development of impoundments. The higher growth in the MRB rivers was attained despite the higher levels of suspended solids in these systems. Roper \& Hickey (1995) suggested that mussels could maintain high levels of nutrition even under high levels of suspended solids by producing copious amount of pseudofeces. This assumes that sufficient food is available even with high levels of suspended solids. Singer \& Gangloff (2011) found higher growth rates below small dams with higher suspended solids but they attributed this to higher levels of organic matter and a higher organic-to-inorganic content. While we assume most of the suspended solids in the MRB are inorganic, it is certainly possible that there are also high levels of organic matter in the water column. Unfortunately, data for volatile suspended solids were not available through the MNPCA website. Finally, Tuttle-Raycraft \& Ackerman (2018) found that the size and quality of suspended solids may influence feeding rates in unionids. They found that clearance rates of mussels in a fine silt treatment were higher than for treatments of mixed sediment, clay or coarse silt. They also found that the fine silt treatment contained more algal particles and had the highest protein and lipid content, suggesting clearance rates are higher on a more nutritious diet. Again, we have no information on the size fractions of suspended solids from our river systems.

While growth was higher in the MRB than the Snake River, there were differences in growth between the species examined. We hypothesize that species displaying equilibrium life history traits would have lower growth rates than those displaying periodic life history traits. In our study, L. cardium had higher growth than A. plicata. This difference is consistent with the idea that $L$. cardium displays periodic life history traits associated with faster growth rates compared to those of an equilibrium species such as A. plicata. The $K$ values from our study for $A$. plicata (0.06-0.11) overlapped with those reported by Haag \& Rypel (2011) (0.07-0.21) while our $L_{\infty}$ levels (152-163 mm) were greater than those reported by Haag \& Rypel (2011) (87-138 mm). The populations described in Haag \& Rypel (2011) are from southern US states (Arkansas, Alabama and Mississippi), which might account for the higher range of growth found. Haag (2012) suggests that slower growing mussels live longer than faster growing mussels thus Rypel \& Haag's (2011) higher growth rates could result in shorter life spans and smaller maximum shell lengths for southern populations. Haag \& Rypel (2011) report that in seven of ten sexually dimorphic species there were significant differences in growth between sexes. These differences were not consistent, in some species females grew faster while in others males grew faster. In most cases, males grew to a larger maximum size than females. In our study, female L. cardium grew faster than males which was opposite of our hypothesis, but males grew to longer sizes in all rivers suggesting males may live longer. It was especially noticeable in the Le Sueur River where female $L$. cardium grew twice as fast as males and had a shell length that was $63 \%$ smaller than males.

There are a number of possibilities to explain why mussel growth and energy storage is higher in rivers with a greater degree of agriculture while mussel abundance and diversity were lower as found by Hornbach et al. (2019). First, lower mussel density found in agriculturally impacted rivers could reduce competition for food and thus individuals could grow larger. Fréchette et al. (1992) found this effect in marine mussel populations. Baker \& Hornbach (2000) showed that native mussels infested with zebra mussels had lower nutritional content and physiological responses than uninfested mussels. They suggested that the native mussels were starving, indicating the possibility of competition for food. Kesler et al. (2007) found that food limitation in lakes resulted in reduced growth and body condition in 
Elliptio complanata. Ferreira-Rodriguez et al. (2018) suggested a similar impact of the invasive Corbicula fluminea on native mussels. Vaughn \& Hakenkamp (2001) and Strayer (2008) both point out that while there may be food limitation for unionid mussels, this is likely only to occur if feeding rates are sufficient to reduce the surrounding food resources. Strayer (2008) goes on to point out that food limitation is likely to occur if the environment is unproductive, feeding rates are high, or if there is a high ratio of inorganic to organic suspended solids. Second, at high levels of suspended solids there could be negative impacts on the availability of sperm for reproduction leading to reduced reproduction. Gascho Landis \& Stoeckel (2016) found that even when the organic matter content of suspended material was high there were negative impacts on reproduction in mussels. Thus, high food availability, which would support higher growth, coupled with high-suspended solids could still result in lower population sizes due to reproductive failure. Gascho Landis et al. (2013) and Gascho Landis \& Stoeckel (2016) found that while increasing TSS resulted in reduced reproduction, there was no impact on growth rates or caloric density supporting the idea that TSS may have differential impacts on recruitment and growth. Third, high ammonia levels, found in rivers with greater amounts of surrounding agriculture land could also lead to recruitment failure. A number of studies have shown that high ammonia levels, especially in sediments, are toxic to juvenile mussels and glochidia (Augspurger et al., 2003; Newton \& Bartsch, 2007; Wang et al., 2008; Strayer \& Malcom, 2013; Bril et al., 2017). Thus, while the number of juveniles may be reduced by high ammonia levels, those that do survive could grow faster because of the greater food resources available in rivers with high nutrient loads. Finally, there could be differences in juvenile survivorship due to differences in bed sediment stability among rivers. Poff et al. (2006) found that areas in the central portions of the US with high levels of agriculture had a decrease in minimum flows and a reduction in flow variability. This likely leads to finer bed sediment substrates with lower stability, which could lead to reduced recruitment of juveniles. Ries et al. (2016) found that discharge levels influenced mussel recruitment, with the highest recruitment when discharge was low in April, but high in July. Arbuckle \& Downing (2002) and Niraula et al. (2017) suggested that high rates of bed sediment accumulation and transport might result in low levels of mussel survival. Similarly, in a side channel of the Upper Mississippi River, survival of four species of adult mussels was strongly influenced by substrate movement during low flow conditions (Newton et al., 2018). The differences in habitat requirements for juvenile and adult mussels could be an explanation for the difference in the impact of increased agricultural land use on abundance and growth in freshwater mussels.

This study, coupled with that of Hornbach et al. (2019), suggest that there are differential impacts of agriculture at the level of the individual and the population/community. These results suggest that additional data are needed to understand the coupling of risk assessment with the level of risk detection. The assessment of adverse outcome pathways and environmental risk (Kramer et al., 2011; Raimondo et al., 2018) is an area of increasing interest among resource managers.

Acknowledgements Funding for this project was provided by the Minnesota Environment and Natural Resources Trust Fund as recommended by the Legislative-Citizen Commission on Minnesota Resources (LCCMR). The Trust Fund is a permanent fund constitutionally established by the citizens of Minnesota to assist in the protection, conservation, preservation and enhancement of the state's air, water, land, fish, wildlife and other natural resources. Sampling help was provided by the following students from Macalester College: Lea Davidson, James (Mac) Doherty and Laura Gould. Will Bouchard of the MN Pollution Control Agency provided water quality data for our sampling areas. We also thank Michelle Bartsch, U.S. Geological Survey and James Stoeckel, Auburn University and anonymous reviewers for Hydrobiologia for comments on earlier drafts of the manuscript. Any use of trade, firm, or product names is for descriptive purposes only and does not imply endorsement by the U.S. Government.

Open Access This article is distributed under the terms of the Creative Commons Attribution 4.0 International License (http:// creativecommons.org/licenses/by/4.0/), which permits unrestricted use, distribution, and reproduction in any medium, provided you give appropriate credit to the original author(s) and the source, provide a link to the Creative Commons license, and indicate if changes were made.

\section{References}

Albertson, L. K. \& D. C. Allen, 2015. Meta-analysis: abundance, behavior, and hydraulic energy shape biotic effects on sediment transport in streams. Ecology 96: 1329-1339.

Aldridge, D. W., B. S. Payne \& A. C. Miller, 1987. The effects of intermittent exposure to suspended solids and turbulence 
on 3 species of freshwater mussels. Environmental Pollution 45: 17-28.

Allen, D. C. \& C. C. Vaughn, 2011. Density-dependent biodiversity effects on physical habitat modification by freshwater bivalves. Ecology 92: 1013-1019.

Anthony, J. L., D. H. Kesler, W. L. Downing \& J. A. Downing, 2001. Length-specific growth rates in freshwater mussels (Bivalvia: Unionidae): extreme longevity or generalized growth cessation? Freshwater Biology 46: 1349-1359.

Arbuckle, K. E. \& J. A. Downing, 2002. Freshwater mussel abundance and species richness: GIS relationships with watershed land use and geology. Canadian Journal of Fisheries and Aquatic Science 59: 310-316.

Atkinson, C. L., C. C. Vaughn, K. J. Forshay \& J. T. Cooper, 2013. Aggregated filter-feeding consumers alter nutrient limitation: consequences for ecosystem and community dynamics. Ecology 94: 1359-1369.

Atkinson, C. L., J. P. Julian \& C. C. Vaughn, 2014. Species and function loss: role of drought in structuring stream communities. Biological Conservation 176: 30-38.

Augspurger, T., A. E. Keller, M. C. Black, W. G. Cope \& F. J. Dwyer, 2003. Water quality guidance for protection of freshwater mussels (Unionidae) from ammonia exposure. Environmental Toxicology and Chemistry 22: 2569-2575.

Baker, S. \& D. J. Hornbach, 2000. Physiological status and biochemical composition of a natural population of unionid mussels (Amblema plicata) infested by zebra mussels (Dreissena polymorpha). American Midland Naturalist 143: 443-452.

Baker, S. \& D. J. Hornbach, 2001. Seasonal metabolism and biochemical composition of two unionid mussels, Actinonaias ligamentina and Amblema plicata. Journal of Molluscan Studies 67: 407-416.

Bartsch, M. R., L. A. Bartsch, W. B. Richardson, J. M. Vallazza \& B. M. Lafrancois, 2017. Effects of food resources on the fatty acid composition, growth and survival of freshwater mussels. PLoS ONE 12: e0173419.

Beggel, S., M. Hinzmann, J. Machado \& J. Geist, 2017. Combined impact of acute exposure to ammonia and temperature stress on the freshwater mussel Unio pictorum. Water 9: 455.

Belmont, P., K. B. Gran, S. P. Schottler, P. R. Wilcock, S. S. Day, C. Jennings, J. W. Lauer, E. Viparelli, J. K. Willenbring, D. R. Engstrom \& G. Parker, 2011. Large shift in source of fine sediment in the upper Mississippi River. Environmental Science \& Technology 45: 8804-8810.

Bright, R. C., C. Gatenby, D. Olson \& E. Plummer, 1990. A survey of the mussels of the Minnesota River, 1989. University of Minnesota Bell Museum of Natural History, St. Paul, MN, 106 pp. (http://files.dnr.state.mn.us/eco/ nongame/projects/consgrant_reports/1990/1990_bright_ etal.pdf) [Accessed June 10, 2018]

Bril, J. S., K. Langenfeld, C. L. Just, S. N. Spak \& T. J. Newton, 2017. Simulated mussel mortality thresholds as a function of mussel biomass and nutrient loading. PEERJ 5: e2838.

Brim Box, J. \& J. Mossa, 1999. Sediment, land use, and freshwater mussels: prospects and problems. Journal of the North American Benthological Society 18: 99-117.

Cao, Y., J. Huang \& K. S. Cummings, 2013. Modeling changes in freshwater mussel diversity in an agriculturally dominated landscape. Freshwater Science 32: 1205-1218.
Cao, Y., A. Stodola, S. Douglass, D. Shasteen, K. Cummings \& A. Holtrop, 2015. Modelling and mapping the distribution, diversity and abundance of freshwater mussels (Family Unionidae) in wadeable streams of Illinois, U.S.A. Freshwater Biology 60: 1379-1397.

Chen, L., A. G. Heath \& R. Neves, 2001. An evaluation of air and water transport of freshwater mussels (Bivalvia: Unionidae). American Malacological Bulletin 16: 147-154.

Chowdhury, G. W., A. Zieritz \& D. C. Aldridge, 2016. Ecosystem engineering by mussels supports biodiversity and water clarity in a heavily polluted lake in Dhaka, Bangladesh. Freshwater Science 35: 188-199.

Downing, W. L., J. Hostell \& J. A. Downing, 1992. Non-annual external annuli in the freshwater mussels Anodonta grandis grandis and Lampsilis radiate siliquoidea. Freshwater Biology 28: 309-317.

Ferreira-Rodriguez, N., R. Sousa \& I. Pardo, 2018. Negative effects of Corbicula fluminea over native freshwater mussels. Hydrobiologia 810: 85-95.

Fréchette, M., A. E. Aitken \& L. Pagé, 1992. Interdependence of food and space limitation of a benthic suspension feeder: consequences for self-thinning relationships. Marine Ecology Progress Series 83: 55-62.

French, S. K. \& J. D. Ackerman, 2014. Responses of newly settled juvenile mussels to bed shear stress: implications for dispersal. Freshwater Science 33: 46-55.

Fritts, A. K., J. T. Peterson, P. D. Hazelton \& R. B. Bringolf, 2015a. Evaluation of methods for assessing physiological biomarkers of stress in freshwater mussels. Canadian Journal of Fisheries and Aquatic Sciences 72: 1450-1459.

Fritts, A. K., J. T. Peterson, P. D. Hazelton \& R. B. Bringolf, 2015b. Nonlethal assessment of freshwater mussel physiological response to changes in environmental factors. Canadian Journal of Fisheries and Aquatic Sciences 72: 1460-1468.

Fritts, A. K., M. W. Fritts, W. R. Haag, J. A. DeBoer \& A. F. Casper, 2017. Freshwater mussel shells (Unionidae) chronicle changes in a North American river over the past 1000 years. Science of the Total Environment 575: 199-206.

Gabbott, P. A. 1975. Storage cycles in marine bivalve molluscs: a hypothesis concerning the relationship between glycogen metabolism and gametogenesis. In Barnes, H. (ed), Proceedings of the 9th European Marine Biology Symposium. Aberdeen University Press, Aberdeen, Scotland: 191-211.

Ganser, A. M., T. J. Newton \& R. J. Haro, 2013. The effects of elevated water temperature on native juvenile mussels: implications for climate change. Freshwater Science 32: 1168-1177.

Garcia, L., W. F. Cross, I. Pardo \& J. S. Richardson, 2017. Effects of landuse intensification on stream basal resources and invertebrate communities. Freshwater Science 36: 609-645.

Gascho Landis, A. M. \& J. A. Stoeckel, 2016. Multi-stage disruption of freshwater mussel reproduction by high suspended solids in short- and long-term brooders. Freshwater Biology 61: 219-228.

Gascho Landis, A. M. G., W. R. Haag \& J. A. Stoeckel, 2013. High suspended solids as a factor in reproductive failure of a freshwater mussel. Freshwater Science 32: 70-81. 
Gustafson, L. L., M. K. Stoskopf, W. Showers, G. Cope, C. Eads, R. Linnehan, T. J. Kwak, B. Andersen \& J. F. Levine, 2005. Reference ranges for hemolymph chemistries from Elliptio complanata of North Carolina. Diseases of Aquatic Organisms 65: 167-176.

Gutiérrez, J. L., C. G. Jones, D. L. Strayer \& O. O. Iribarne, 2003. Mollusks as ecosystems engineers: the role of shell production in aquatic habitats. Oikos 101: 79-90.

Haag W. R. 2012. North American Freshwater Mussels: Natural History, Ecology, and Conservation. Cambridge University Press, Cambridge, UK, 505 pp.

Haag, W. R. \& A. M. Commens-Carson, 2008. Testing the assumption of annual shell ring deposition in freshwater mussels. Canadian Journal of Fisheries and Aquatic Sciences 65: 493-508.

Haag, W. R. \& A. L. Rypel, 2011. Growth and longevity in freshwater mussels: evolutionary and conservation implications. Biological Reviews 86: 225-247.

Haag, W. R., D. L. Berg, D. W. Garton \& J. L. Farris, 1993. Reduced survival and fitness in native bivalves in response to fouling by the introduced zebra mussel (Dreissena polymorpha in Western Lake Erie. Canadian Journal of Fisheries and Aquatic Sciences 50: 13-19.

Hansen, A. T., J. A. Czuba, J. Schwenk, A. Longjas, M. DaneshYazdi, D. J. Hornbach \& E. Foufoula-Georgiou, 2016. Coupling freshwater mussel ecology and river dynamics using a simplified dynamic interaction model. Freshwater Science 35: 200-215.

Helama, S., I. Valovirta \& J. K. Nielsen, 2017. Growth characteristics of the endangered thick-shelled river mussel (Unio crassus) near the northern limit of its natural range. Aquatic Conservation: Marine and Freshwater Ecosystems 27: 476-491.

Helton, A. M., G. C. Poole, J. L. Meyer, W. M. Wollheim, B. J. Peterson, P. J. Mulholland, E. S. Bernhardt, J. A. Stanford, C. Arango, L. R. Ashkenas, L. W. Cooper, W. K. Dodds, S. V. Gregory, R. O. Hall Jr., S. K. Hamilton, S. L. Johnson, W. H. McDowell, J. D. Potter, J. L. Tank, S. M. Thomas, H. M. Valett, J. R. Webster \& L. Zeglin, 2011. Thinking outside the channel: modeling nitrogen cycling in networked river ecosystems. Frontiers in Ecology and the Environment 9: 229-238.

Hladyz, S., K. Abjornsson, E. Chauvet, M. Dobson, A. Elosegi, V. Ferreira, T. Fleituch, M. O. Gessner, P. S. Giller, V. Gulis, S. A. Hutton, J. O. Lacoursière, S. Lamothe, A. Lecerf, B. Malmqvist, B. G. McKie, M. Nistorescu, E. Preda, M. Riipinen, G. Rîsnoveanu, M. Schindler, S. D. Tiegs, L. B.-M. Vought \& G. Woodward, 2011. Stream ecosystem functioning in an agricultural landscape: the importance of terrestrial-aquatic linkages. Advances in Ecological Research 44: 211-276.

Hornbach, D. J., C. M. Way, T. E. Wissing \& A. J. Burky, 1984. Effects of particle concentration and season on the filtration rates of the freshwater clam, Sphaerium striatinum Lamarck (Bivalvia: Pisidiidae) and their role in the nutrient dynamics of a woodland stream. Hydrobiologia 108: 83-96.

Hornbach, D. J., M. C. Hove, H. Liu, F. R. Schenck, D. Rubin \& B. J. Sansom, 2014. The influence of two differently sized dams on mussel assemblages and growth. Hydrobiologia 724: 279-291.
Hornbach D. J., M. C. Hove, K. R. MacGregor, J. Kozarek, B. Sietman \& M. Davis, 2019. The impact of agricultural land use on freshwater mussel assemblages: a comparison of two Minnesota watersheds. Aquatic Conservation: Marine and Freshwater Ecosystems

Hua, D., Y. Jiao, R. Neves \& J. Jones, 2016. Periodic growth and growth cessations in the federally endangered freshwater mussel Cumberlandian combshell using a hierarchical Bayesian approach. Endangered Species Research 31: 325-336.

Johnson, H. G., S. C. Gupta, A. V. Vecchia \& F. Zvomuya, 2009a. Assessment of water quality trends in the Minnesota River using non-parametric and parametric methods. Journal of Environmental Quality 38: 1018-1030.

Johnson, H. G., S. C. Gupta, A. V. Vecchia \& F. Zvomuya, 2009b. Assessment of water quality trends in the Minnesota River using non-parametric and parametric methods - errata. Journal of Environmental Quality 38: 1782.

Kesler, D. H., T. J. Newton \& L. Green, 2007. Long term monitoring of growth in the Eastern Elliptio (Elliptio complanata) in southern New England: a transplant experiment. Journal of the North American Benthological Society 26: 123-133.

Klunzinger, M. W., S. J. Beatty, D. L. Morgan, A. J. Lymbery \& W. R. Haag, 2014. Age and growth in the Australian freshwater mussel, Westralunio carteri, with an evaluation of the fluorochrome calcein for validating the assumption of annulus formation. Freshwater Science 33: 1127-1135.

Kramer, V. J., M. A. Etterson, M. Hecker, C. A. Murphy, G. Roesijadi, D. J. Spade, J. A. Spromberg, M. Wang \& G. T. Ankley, 2011. Adverse outcome pathways and ecological risk assessment: bridging to population-level effects. Environmental Toxicology and Chemistry 30: 64-76.

Lenz, B. N., D. M. Robertson, J. D. Fallon \& R. Ferrin, 2003. Nutrient and suspended-sediment concentrations and loads, and benthic- invertebrate data for tributaries to the St. Croix River, Wisconsin and Minnesota, 1997-99. U.S. Geological Survey Water-Resources Investigations: Report 01-4162.

Lopes-Lima, M., L. E. Burlakova, A. Y. Karatayev, K. Mehler, M. Seddon \& R. Sousa, 2018. Conservation of freshwater bivalves at the global scale: diversity, threats and research needs. Hydrobiologia 810: 1-14.

McGoldrick, D. J., J. Metcalfe-Smith, M. T. Arts, D. W. Schloesser, T. J. Newton, G. L. Mackie, E. M. Monroe, J. Biberhofer \& K. Johnson, 2009. Characteristics of a refuge for native freshwater mussels (Bivalvia: Unionidae) in Lake St. Clair. Journal of Great Lakes Research 35: 137-146.

MN DNR, 2007. Ask the expert about the Minnesota River: mussel overview. (http://mrbdc.mnsu.edu/sites/mrbdc. mnsu.edu/files/public/pdf/askexpert/mussel_overview. pdf) [Accessed June 10, 2018].

Monroe, E. M. \& T. J. Newton, 2001. Seasonal variation in physiological condition of Amblema plicata in the Upper Mississippi River. Journal of Shellfish Research 20: 1167-1171.

Moore, J. W., 1977. Some aspects of feeding biology of benthic herbivores. Hydrobiologia 53: 139-146. 
Morris, T. J. \& L. D. Corkum, 1999. Unionid growth patterns in rivers of differing riparian vegetation. Freshwater Biology 42: 59-68.

Musser K., S. Kudelka \& R. Moore, 2009. Minnesota River Basin Trends. Mankato State University, Mankato, MN, 64 pp. (http://mrbdc.mnsu.edu/sites/mrbdc.mnsu.edu/files/ public/mnbasin/trends/pdfs/trends_full.pdf) [Accessed June 10, 2018].

Naimo, T. J. \& E. M. Monroe, 1999. Variation in glycogen concentrations within mantle and foot tissue in Amblema plicata plicata: implications for tissue biopsy sampling. American Malacological Bulletin 15: 51-56.

Naimo, T. J., E. D. Damschen, R. G. Rada \& E. M. Monroe, 1998. Nonlethal evaluation of the physiological health of Unionid mussels: methods for biopsy and glycogen analysis. Journal of the North American Benthological Society 17: 121-128.

Negishi J.N., S. Sagawa, Y. Kayaba, S. Sanada, M. Kume \& T. Miyashita, 2012. Mussel responses to flood pulse frequency: the importance of local habitat. Freshwater Biology 57: 1500-1511

Negishi, J. N., S. Sagawa, Y. Kayaba, S. Sanada, M. Kume \& T. Miyashita, 2014a. Mussel responses to flood pulse frequency: the importance of local habitat. Freshwater Biology 57: 1500-1511.

Negishi, J. N., K. Katsuki, M. Kume, S. Nagayama \& Y. Kayaba, 2014b. Terrestrialization alters organic matter dynamics and habitat quality for freshwater mussels (Unionoida) in floodplain backwaters. Freshwater Biology 59: 1026-1038.

Newton, T. J. \& M. R. Bartsch, 2007. Lethal and sublethal effects of ammonia to juvenile Lampsilis mussels (Unionidae) in sediment and water-only exposures. Environmental Toxicology and Chemistry 26: 2057-2065.

Newton, T. J., E. M. Monroe, R. Kenyon, S. Gutreuter, K. I. Welke \& P. A. Thiel, 2001. Evaluation of relocation of unionid mussels into artificial ponds. Journal of the North American Benthological Society 20: 468-485.

Newton, T. J., D. A. Woolnough \& D. L. Strayer, 2008. Using landscape ecology to understand and manage freshwater mussel populations. Journal of the North American Benthological Society 27: 424-439.

Newton, T. J., S. J. Zigler, J. T. Rogala, B. R. Gray \& M. Davis, 2011. Population assessment and potential functional roles of native mussels in the Upper Mississippi River. Aquatic Conservation: Marine and Freshwater Ecosystems 21: 122-131.

Newton, T., S. Zigler, P. Ries, M. Davis, R. Kennedy, \& D. Smith, 2018. Estimation of vital rates to assess the relative health of mussel resources in the Upper Mississippi River System. Final report to the U.S. Army Corps of Engineers, Rock Island, IL. 40 pp.

Niraula, B. B., J. M. Hyde, J. M. Miller \& P. M. Stewart, 2017. Differential sediment stability for two federally threatened and one common species of freshwater mussels in Southeastern Coastal Plain Streams, USA. Journal of Freshwater Ecology 32: 85-94.

Novotny, E. V. \& H. G. Stefan, 2007. Stream flow in Minnesota: Indicator of climate change. Journal of Hydrology 334: 319-333.
Österling, E. M., 2015. Timing, growth and proportion of spawners of the threatened unionoid mussel Margaritifera margaritifera: influence of water temperature, turbidity and mussel density. Aquatic Sciences 77: 1-8.

Österling, M. E., B. L. Arvidsson \& L. A. Greenberg, 2010. Habitat degradation and the decline of the threatened mussel Margaritifera margaritifera: influence of turbidity and sedimentation on the mussel and its host. Journal of Applied Ecology 47: 759-768.

Patterson, M. A., B. C. Parker \& R. J. Neves, 1999. Glycogen concentration in the mantle tissue of freshwater mussels (Bivalvia: Unionidae) during starvation and controlled feeding. American Malacological Bulletin 15: 47-50.

Payne, B. S., A. C. Miller \& L. R. Shaffer, 1999. Physiological resilience of freshwater mussels to turbulence and suspended solids. Journal of Freshwater Ecology 14: 265-276.

Payton, S. L., P. D. Johnson \& M. J. Jenny, 2016. Comparative physiological, biochemical and molecular thermal response profiles for two unionid freshwater mussel species. Journal of Experimental Biology 219: 3562-3574.

Poff, N. L., B. P. Bledsoe \& C. O. Cuhaciyan, 2006. Hydrologic variation with land use across the contiguous United States: Geomorphic and ecological consequences for stream ecosystems. Geomorphology 79: 264-285.

Poole, K. E. \& J. A. Downing, 2004. Relationship of declining biodiversity to stream-reach and watershed characteristics in an agricultural landscape. Journal of the North American Benthological Society 23: 114-125.

Raimondo, S., M. Etterson, N. Pollesch, K. Garber, A. Kanarek, W. Lehmann \& J. Awkerman, 2018. A framework for linking population model development with ecological risk assessment. Integrated Environmental Assessment and Management 14: 369-380.

Randklev, C. R., N. Ford, S. Wolverton, J. H. Kennedy, C. Robertson, K. Mayes \& D. Ford, 2016. The influence of stream discontinuity and life history strategy on mussel community structure: a case study from the Sabine River, Texas. Hydrobiologia 770: 173-191.

Reid, N., A. Keys, J. S. Preston, E. Moorkens, D. Roberts \& C. D. Wilson, 2012. Conservation status and reproduction of the critically endangered freshwater pearl mussel (Margaritifera margaritifera) in Northern Ireland. Aquatic Conservation: Marine and Freshwater Ecosystems 23: 571-581.

Ries, P. R., T. J. Newton, R. J. Haro, S. J. Zigler \& M. Davis, 2016. Inter-annual variation in recruitment of freshwater mussels and its relationship with river discharge. Aquatic Conservation: Marine and Freshwater Ecosystems 26: 703-714.

Roper, D. S. \& C. W. Hickey, 1995. Effect of food and silt on filtration, respiration and condition of the fresh-water mussel Hydidella-menziesi (Unionacea, Hydriidae) implications for bioaccumulation. Hydrobiologia 312: $17-25$.

Sansom, B. J., D. J. Hornbach, M. C. Hove \& J. S. Kilgore, 2013. Effects of flow restoration on mussel growth in a Wild and Scenic North American River. Aquatic Biosystems 9: 6

Sansom, B. J., C. L. Atkinson \& C. C. Vaughn, 2016. Growth and longevity estimates for mussel populations in three Ouachita Mountain Rivers. Freshwater Mollusk Biology and Conservation 19: 19-26. 
Schilling, K. E., P. Jindal, N. B. Basu \& M. J. Helmers, 2012. Impact of artificial subsurface drainage on groundwater travel times and baseflow discharge in an agricultural watershed, Iowa (USA). Hydrological Processes 26: 3092-3100.

Schottler, S. P., J. Ulrich, P. Belmont, R. Moore, J. W. Lauer, D. R. Engstrom \& J. E. Almendinger, 2014. Twentieth century agricultural drainage creates more erosive rivers. Hydrological Processes 28: 1951-1961.

Singer, E. E. \& M. M. Gangloff, 2011. Effects of a small dam on freshwater mussel growth in Alabama (U.S.A.) stream. Freshwater Biology 56: 1904-1915.

Spooner, D.E., \& C. C. Vaughn, 2008. A trait-based approach to species' roles in stream ecosystems: climate change, community structure, and material cycling. Oecologia 158 : 307-317

Stetten Jr., D. \& M. R. Stetten, 1960. Glycogen metabolism. Physiological Reviews 40: 505-537.

Stoeckel, K. \& J. Geist, 2016. Hydrological and substrate requirements of the thick-shelled river mussel Unio crassus (Philipsson 1788). Aquatic Conservation: Marine and Freshwater Ecosystems 26: 456-469.

Strayer, D. L., 2008. Freshwater Mussel Ecology: A Multifactor Approach to Distribution and Abundance. University of California Press, Berkeley, CA, 204 pp.

Strayer, D. L., 2014. Understanding how nutrient cycles and freshwater mussels (Unionoida) affect one another. Hydrobiologia 735: 277-292.

Strayer, D. L. \& A. R. Fetterman, 1999. Changes in the distribution of freshwater mussels (Unionidae) in the upper Susquehanna River basin, 1955-1965 to 1996-1997. American Midland Naturalist 142: 328-339.

Strayer, D. L. \& H. M. Malcom, 2013a. Long-term change in the Hudson River's bivalve populations: a history of multiple invasions (and recovery?). In Nalepa, T. F. \& D. W. Schlosser (eds), Quagga and Zebra Mussels: Biology, Impacts, and Control: 2. CRC Press, London: 71-81.

Strayer, D. L. \& H. M. Malcom, 2013b. Long-term change in the Hudson River's bivalve populations: a history of multiple invasions (and recovery?). In Nalepa, T. F. \& D. W. Schlosser (eds), Quagga and Zebra Mussels: Biology, Impacts, and Control: 2. CRC Press, London: 71-81.

Strayer, D. L., J. A. Downing, W. R. Haag, T. L. King, J. B. Layzer, T. J. Newton \& S. J. Nichols, 2004. Changing perspectives on pearly mussels, North America's most imperiled animals. BioScience 54: 429-439.

Tuttle-Raycraft, S. \& J. D. Ackerman, 2018. Does size matter? Particle size vs. quality in bivalve suspension feeding. Freshwater Biology. https://doi.org/10.1111/fwb.13184.
Tuttle-Raycraft, S., T. J. Morris \& J. D. Ackerman, 2017. Suspended solid concentration reduces feeding in freshwater mussels. Science of the Total Environment 598: 1160-1168.

Vaughn, C. C. \& C. C. Hakenkamp, 2001. The functional role of burrowing bivalves in freshwater ecosystems. Freshwater Biology 46: 1431-1446.

Waller, D.L., S. Gutreuter \& J.J. Rach, 1999. Behavioral responses to disturbance in freshwater mussels with implications for conservation and management. Journal of the North American Benthological Society 18: 381-390

Wang, N., R. J. Erickson, C. G. Ingersoll, C. D. Ivey, E. L. Brunson, T. Augspurger \& M. C. Barnhart, 2008. Influence of $\mathrm{pH}$ on the acute toxicity of ammonia to juvenile freshwater mussels (fatmucket, Lampsilis siliquoidea). Environmental Toxicology and Chemistry 27: 1141-1146.

Waters, T. F., 1977. The Streams and Rivers of Minnesota. University of Minnesota Press, Minneapolis, $384 \mathrm{pp}$.

Williams, J. D., A. E. Bogan, R. S. Butler, K. S. Cummings, J. T. Garner, J. L. Harris, N. A. Johnson \& G. T. Watters, 2017. A revised list of the freshwater mussels (Mollusca: Bivalvia: Unionida) of the United States and Canada. Freshwater Mollusk Biology and Conservation 20: 33-58.

Woodward, G., M. O. Gessner, P. S. Giller, V. Gulis, S. Hladyz, A. Lecerf, B. Malmqvist, B. G. McKie, S. D. Tiegs, H. Cariss, M. Dobson, A. Elosegi, V. Ferreira, M. A. Graça, T. Fleituch, J. O. Lacoursière, M. Nistorescu, J. Pozo, G. Risnoveanu, M. Schindler, A. Vadineanu, L. B. Vought \& E. Chauvet, 2012. Continental-scale effects of nutrient pollution on stream ecosystem functioning. Science 336 : 1438-1440.

Yuan, F., M. Mitchell, B. Bohks, K. Mullen \& C. Smith, 2015. Long-term land use and land cover changes affected by the conservation reserve program in the Minnesota River Valley. Journal of Geography and Geology 7: 105-116.

Zieritz, A. \& D. C. Aldridge, 2009. Identification of ecophenotypic trends within three European freshwater mussel species (Bivalvia: Unionoida) using traditional and modern morphometric techniques. Biological Journal of the Linnean Society 98: 814-825.

Publisher's Note Springer Nature remains neutral with regard to jurisdictional claims in published maps and institutional affiliations. 